\title{
Effect of lipid supplementation on milk odd- and branched-chain fatty acids in dairy cows
}

\author{
E. Baumann, P. Y. Chouinard, Y. Lebeuf, D. E. Rico, and R. Gervais ${ }^{1}$ \\ Département des Sciences Animales, Université Laval, 2425 rue de l'Agriculture, Québec, Canada, G1V 0A6
}

\section{ABSTRACT}

Eight ruminally fistulated, multiparous Holstein cows were arranged in a double $4 \times 4$ Latin square with 14-d periods to investigate the effects of lipid supplementation on performance, rumen parameters, the milk odd- and branched-chain fatty acid (OBCFA) profile, and the relationships between milk OBCFA and rumen parameters. Lipid supplementation is known to inhibit microbial growth in the rumen, decrease de novo microbial fatty acid synthesis, and increase the uptake of circulating fatty acids by the mammary gland; treatments were selected to isolate these effects on the milk OBCFA profile. The 4 treatments were (1) a lipid-free emulsion medium infused in the rumen (CTL), (2) soybean oil as a source of polyunsaturated fatty acids infused in the rumen (RSO), (3) saturated fatty acids (38\% 16:0, $40 \%$ 18:0) infused in the rumen (RSF), and (4) saturated fatty acids infused in the abomasum (ASF). Fat supplements were provided continuously as emulsions at a rate of $450 \mathrm{~g} / \mathrm{d}$. Preplanned contrasts compared CTL to RSO, RSO to RSF, and RSF to ASF. Infusing RSO slightly decreased ruminal $\mathrm{pH}$, but did not affect volatile fatty acids profile and milk fat concentration as compared with CTL. The yields of energy-corrected milk, fat, and protein were greater with RSF compared with RSO. The concentration of odd-chain fatty acids was decreased by RSO, whereas even-chain iso fatty acids were not affected. Milk fat concentration of 17:0 + cis-9 17:1 was higher for RSF than for RSO, due to the saturated fatty acids supplement containing 2\% $17: 0$ + cis-9 17:1. Limited differences were observed in the milk OBCFA profile between RSF and ASF. A multiple regression analysis yielded the following equation for predicting rumen $\mathrm{pH}$ based on milk fatty acids: $\mathrm{pH}=$ $6.24-(0.56 \times 4: 0)+(1.67 \times$ iso $14: 0)+(4.22 \times$ iso $15: 0)+(9.41 \times 22: 0)$. Rumen propionate concentration was negatively correlated with milk fat concentration of iso 14:0 and positively correlated with milk 15:0, whereas the acetate-to-propionate ratio gave the op-

Received December 10, 2015.

Accepted April 1, 2016.

${ }^{1}$ Corresponding author: rachel.gervais@fsaa.ulaval.ca posite correlations with milk iso 14:0 and 15:0. Milk fat concentration of 17:0 + cis-9 17:1 was not related to rumen propionate or to acetate-to-propionate ratio, due to the presence of $17: 0$ and cis-9 17:1 in the saturated fatty acids supplement. The results suggest that although lipid supplementation can affect the profile of milk OBCFA, the promise remains of using these milk fatty acids to evaluate rumen function.

Key words: odd- and branched-chain fatty acids, soybean oil, prilled fat, rumen fermentation, milk fat

\section{INTRODUCTION}

Fat supplementation in the nutrition of lactating dairy cows is an approach used to increase the energy density of the ration. In early-lactation cows, this feeding practice limits the extent of the negative energy balance which may support milk yield (Palmquist and Jenkins, 1980). However, lipid supplementation may affect various metabolic processes which determine the fatty acid (FA) profile of milk. It is well documented that the inclusion of supplemental lipids in the diet can alter the rumen environment, affecting microbial fermentation and VFA production (Ferguson et al., 1990; Jenkins and Jenny, 1992; Harvatine and Allen, 2006b). Further, PUFA, such as cis-9,cis-12 18:2, a predominant FA in soybean oil (approximately 50\%), have been shown to be toxic to rumen microbiota, particularly cellulolytic bacteria (Maia et al., 2007), and thereby, inclusion of such lipid supplements may decrease the levels of FA of microbial origin in milk (mechanism 1). Lipid supplementation may also change the milk FA profile by increasing uptake of dietary FA by rumen microbes, thereby decreasing the proportion of de novo synthesized microbial FA, as reported by Emmanuel (1978), and Weisbjerg et al. (1992; mechanism 2). Finally, lipid supplementation may also directly affect FA synthesis by the mammary gland, either by increasing uptake of preformed FA (Palmquist et al., 1993; mechanism 3), or by inhibiting mammary gland lipogenesis through rumen synthesis of the CLA isomer trans-10,cis-12 18:2 (Bauman and Griinari, 2001; mechanism 4).

Odd- and branched-chain FA (OBCFA) found in ruminant tissues are predominantly produced by ruminal 
Table 1. Feed and chemical composition of basal diet

\begin{tabular}{lc}
\hline Item & Content \\
\hline Ingredient, \% of DM & \\
Grass silage & 39.7 \\
Corn silage & 24.1 \\
Dry ground corn & 25.8 \\
Corn gluten meal & 5.5 \\
Soybean meal & 2.4 \\
Vitamin and mineral mix ${ }^{1}$ & 1.7 \\
Sodium bicarbonate & 0.8 \\
Chemical composition & \\
DM, \% as fed & 44.8 \\
OM, \% of DM & 92.8 \\
NDF, \% of DM & 26.4 \\
ADF, \% of DM & 20.5 \\
CP, \% of DM & 18.0 \\
Fatty acids, mg/g of DM & \\
16:0 0 & 4.7 \\
18:0 0 18:1 & 1.1 \\
cis-11 18:1 & 6.5 \\
cis-9, cis-12 18:2 & 0.3 \\
cis-9, cis-12,cis-15 18:3 & 14.1 \\
Tothers & 4.4 \\
Total & 0.4 \\
\hline
\end{tabular}

${ }^{1}$ Contained, on a DM basis, $18.00 \% \mathrm{Ca}, 5.00 \% \mathrm{P}, 6.00 \% \mathrm{Mg}, 0.06 \% \mathrm{~K}$, $9.50 \% \mathrm{Na}, 15.00 \% \mathrm{Cl}, 1.00 \% \mathrm{~S}, 3,620 \mathrm{mg} / \mathrm{kg}$ of Fe, $45 \mathrm{mg} / \mathrm{kg}$ of I, 600 $\mathrm{mg} / \mathrm{kg}$ of $\mathrm{Cu}, 2,000 \mathrm{mg} / \mathrm{kg}$ of $\mathrm{Mn}, 3,000 \mathrm{mg} / \mathrm{kg}$ of $\mathrm{Zn}, 25 \mathrm{mg} / \mathrm{kg}$ of $\mathrm{Se}, 20 \mathrm{mg} / \mathrm{kg}$ of Co, $300 \mathrm{kIU}$ of vitamin A, $100 \mathrm{kIU}$ of vitamin $\mathrm{D}$, and $1,500 \mathrm{IU}$ of vitamin $\mathrm{E}$.

${ }^{2}$ Other fatty acids included minor concentrations of 12:0, 14:0, 15:0, 16:1, and 17:0.

microorganisms (Keeney et al., 1962; Harfoot, 1981), although a small proportion could come from postruminal synthesis (Massart-Leën et al., 1986; Vlaeminck et al., 2015). Different groups of rumen microbial species have unique OBCFA profiles (Vlaeminck et al., 2006a). Cellulolytic bacteria synthesize more iso FA, whereas amylolytic bacteria produce elevated levels of anteiso and linear odd-chain FA and relatively low levels of iso FA (Fievez et al., 2012). The intestinal absorption of microbially produced OBCFA and their uptake by the mammary gland lead to the appearance of OBCFA in milk fat of lactating dairy cows. Given that lipid supplementation can affect the various steps which determine milk FA profile, it is of interest to evaluate how the OBCFA profile of milk is affected by the presence of supplementary lipids in the diet.

The review by Fievez et al. (2012) of milk OBCFA and their relationship to rumen function indicates that iso 14:0 and iso 16:0 in milk are positively related to rumen acetate production, whereas milk 15:0 and 17:0 are negatively related to rumen acetate production and positively related to propionate production. Therefore, the OBCFA profile of the milk could potentially be used as a noninvasive method to predict certain aspects of rumen function. The first objective of the present experiment was to investigate the effects of lipid supple- mentation on the aforementioned mechanisms of milk fat synthesis as well as on animal performance, rumen parameters, and milk OBCFA. An additional objective was to estimate the effect of lipid supplementation on the relationship between milk OBCFA and rumen function.

\section{MATERIALS AND METHODS}

\section{Cows, Feeding, and Treatments}

All procedures involving animals were conducted according to the regulations of the Canadian Council on Animal Care (1993), and were approved by the Université Laval Animal Care Committee. Eight ruminally fistulated, multiparous Holstein cows (BW: $698 \pm 56$ $\mathrm{kg})$ in midlactation $(101 \pm 11$ DIM) were housed in a tiestall facility at the Centre de Recherche en Sciences Animales de Deschambault (Deschambault, QC, Canada). Cows received a TMR (Table 1) formulated to meet predicted nutrient requirements (NRC, 2001). Cows were fed once per day at $1000 \mathrm{~h}$, and always had free access to water. Samples of silages used in the TMR were taken once a week and oven-dried at $55^{\circ} \mathrm{C}$ for $48 \mathrm{~h}$ to determine DM content. The TMR was subsequently recalculated to maintain similar proportions of feed ingredients on a DM basis. Feed refused was weighed daily before feeding, and the amount of feed offered was adjusted to maintain $10 \%$ refusals.

Cows were arranged in a double $4 \times 4$ Latin square design with 14-d periods. For the duration of each period, cows received 1 of the following 4 treatments, which were all prepared as emulsions: (1) a ruminally infused lipid-free emulsion medium used as the control (CTL); (2) $450 \mathrm{~g} / \mathrm{d}$ of a ruminally infused PUFA supplement [soybean oil, Soya Excel, Beloeil, QC, Canada, (RSO)] with putative effects on mechanisms 1 to 4 ; (3) $450 \mathrm{~g} / \mathrm{d}$ of a ruminally infused SFA supplement [Energy Booster 100, Milk Specialties Global, Eden Prairie, MN, (RSF)] with putative effect on mechanisms 2 and 3; or (4) 450 $\mathrm{g} / \mathrm{d}$ of an abomasally infused SFA supplement (ASF) with putative effect on mechanism 3. The FA profile of the experimental fat supplements is presented in Table 2. At $0900 \mathrm{~h}$ on $\mathrm{d} 14$ of each period, $5 \mathrm{~L}$ of rumen content were transferred from cows who had received a specific treatment during the previous $14 \mathrm{~d}$ to cows that would receive that treatment for the next $14 \mathrm{~d}$ to decrease the time required for rumen adaptation to the new treatment.

\section{Preparation of Emulsions and Infusion Procedure}

Emulsions were prepared following the procedure described by Drackley et al. (1992) with modifications 
Table 2. Fatty acid profile of experimental fat supplements

\begin{tabular}{|c|c|c|}
\hline $\begin{array}{l}\text { Fatty acids, } \% \\
\text { of total fatty acids }\end{array}$ & $\begin{array}{l}\text { Soybean } \\
\text { oil }^{1}\end{array}$ & $\mathrm{SFA}^{2}$ \\
\hline $8: 0$ & - & 0.80 \\
\hline 10:0 & - & 0.16 \\
\hline $12: 0$ & - & 0.73 \\
\hline 14:0 & 0.08 & 3.16 \\
\hline iso $15: 0$ & - & 0.08 \\
\hline anteiso 15:0 & - & 0.07 \\
\hline cis-9 14:1 & - & 0.11 \\
\hline $15: 0$ & - & 0.56 \\
\hline iso 16:0 & - & 0.14 \\
\hline $16: 0$ & 11.77 & 37.79 \\
\hline trans-9 16:1 & - & 0.07 \\
\hline iso $17: 0$ & - & 0.35 \\
\hline cis-9 16:1 & 0.09 & 0.33 \\
\hline anteiso $17: 0$ & - & 0.43 \\
\hline $17: 0$ & 0.13 & 1.87 \\
\hline iso $18: 0$ & - & 0.16 \\
\hline cis-9 17:1 & - & 0.07 \\
\hline 18:0 & 3.93 & 39.93 \\
\hline trans-6-8 18:1 & - & 0.50 \\
\hline trans-9 18:1 & - & 0.82 \\
\hline trans-10 18:1 & - & 1.80 \\
\hline trans-11 18:1 & - & 0.88 \\
\hline trans-12 18:1 & - & 0.29 \\
\hline cis-9 18:1 & 18.78 & 6.50 \\
\hline trans-15 18:1 & - & 0.19 \\
\hline cis-11 18:1 & 1.42 & 0.30 \\
\hline cis-12 18:1 & - & 0.10 \\
\hline cis-13 18:1 & - & 0.14 \\
\hline trans-16 18:1 & - & 0.23 \\
\hline 19:0 & - & 0.20 \\
\hline cis-9,cis-12 18:2 & 56.52 & 0.66 \\
\hline 20:0 & 0.34 & 0.49 \\
\hline cis-9,cis-12,cis-15 18:3 & 6.35 & 0.06 \\
\hline cis-11 20:1 & 0.16 & 0.07 \\
\hline
\end{tabular}

${ }^{1}$ Soya Excel Inc., Beloeil, QC, Canada.

${ }^{2}$ Energy Booster 100, Milk Specialties Global, Eden Prairie, MN.

(Dallaire et al., 2014). The emulsions were prepared on a weekly basis, and were stored at $4^{\circ} \mathrm{C}$ until utilization. The ingredient composition of experimental emulsions is presented in Table 3. Emulsions were ruminally infused using Nalgene tubing ( $4.8 \mathrm{~mm}$ i.d., 1.6-mm wall; Fisher Scientific, Ottawa, ON, Canada) that was passed through the rumen fistula (CTL, RSO, and RSF) or abomasally infused (ASF; Gressley et al., 2006). A peristaltic pump (Masterflex, Cole-Parmer Instrument Company, Montréal, QC, Canada) was used to continuously infuse the emulsions at a rate of $5.5 \mathrm{~kg} / \mathrm{d}$ so that cows received $450 \mathrm{~g} / \mathrm{d}$ of the lipid supplements (Table 3). Infusions started on $\mathrm{d} 0$ of each period at $1000 \mathrm{~h}$ and ended on d 14 at $0900 \mathrm{~h}$.

\section{Experimental Measurements, Sampling, and Analyses}

Cow Weights, DMI, and TMR. Cows were weighed at $1430 \mathrm{~h}$ on $\mathrm{d} 0,1$, and 2 of each period, and again for 3 consecutive days at the end of the ex- periment. Feed offered and refused was weighed, and samples of the TMR were collected from d 9 to 13 . Samples were dried at $55^{\circ} \mathrm{C}$ for $48 \mathrm{~h}$ to determine DM content, and then ground to $2 \mathrm{~mm}$ using a Wiley mill (model 4, Arthur H. Thomas Co., Philadelphia, PA). After being pooled by period, samples were ground to $1 \mathrm{~mm}$ using a Cyclotec Sample Mill (model 1093, Tecator Inc., Höganäs, Sweden). Pooled TMR samples were analyzed according to the following methods: residual moisture (method 934.01; AOAC International, 2005), ADF [Ankom Technology (Fairport, NY) method 5: ADF in feeds - filter bag technique for A200; solutions as in method 973.18, AOAC International (2005)], NDF [Ankom Technology method 6: NDF in feeds-filter bag technique for A200; solutions as in Van Soest et al. (1991) with the inclusion of heat-stable $\alpha$-amylase], CP [N × 6.25; method 968.06, AOAC International (2005)].

Dietary FA were directly transesterified, and FAME were extracted following the method described by Jenkins (2010) with modifications (Villeneuve et al., 2013). Fatty acid profile was determined with a gas chromatograph (Clarus 680; Perkin Elmer, Waltham, MA) equipped with a polar capillary column (HP-Innowax 30-m length, $0.320 \mathrm{~mm}$ i.d., $0.25 \mu \mathrm{m}$ film thickness; Agilent Technologies Canada Inc., Mississauga, ON, Canada) and a flame ionization detector. At the time of the sample injection $(1 \mu \mathrm{L})$ the column temperature was maintained at $185^{\circ} \mathrm{C}$ for $0.5 \mathrm{~min}$, and then increased at $3^{\circ} \mathrm{C} / \mathrm{min}$ to $220^{\circ} \mathrm{C}$. Inlet and detector temperatures were at 240 and $250^{\circ} \mathrm{C}$, respectively, and the split ratio was 50:1. The flow rate for hydrogen carrier gas was 1 $\mathrm{mL} / \mathrm{min}$.

Milk. Cows were milked twice daily at 0700 and 1700 h. Milk yield was recorded and samples were taken at

Table 3. Amount of lipid emulsion ingredients and fat supplements infused on a daily basis

\begin{tabular}{lrrc}
\hline & \multicolumn{3}{c}{ Treatment $^{1}$} \\
\cline { 2 - 4 } Ingredient, g & CTL & RSO & RSF/ASF \\
\hline Tap water & 5,431 & 4,981 & 4,981 \\
Whey protein concentrate ${ }^{2}$ & 48 & 48 & 48 \\
Tween 80 & 21 & 21 & 21 \\
Fat supplement & & 450 & - \\
Soybean oil & \\
Energy Booster $100^{5}$ & - & - & 450 \\
Total emulsion & 5,500 & 5,500 & 5,500 \\
\hline${ }^{1}$ CTL = control; RSO = soybean oil as a source of PUFA infused into \\
the rumen; RSF = SFA infused into the rumen; ASF = SFA infused \\
into the abomasum. \\
${ }^{2}$ AMP 80, American Meat Protein Corporation, Boone, IA. \\
${ }^{3}$ Fisher Scientific, Fair Lawn, NJ. \\
${ }^{4}$ Soya Excel Inc., Beloeil, QC, Canada. \\
${ }^{5}$ Milk Specialties Global, Eden Prairie, MN.
\end{tabular}


each milking from d 9 to 13 of each period. A first subsample was stored at $4^{\circ} \mathrm{C}$ with bronopol as preservative before being analyzed for fat, protein, and lactose by Valacta (Dairy Production Centre of Expertise, Ste-Anne-de-Bellevue, QC, Canada) using an infrared procedure with a Foss MilkoScan FT 6000 instrument (Foss, Hillerød, Denmark).

A second subsample was stored at $-20^{\circ} \mathrm{C}$ without preservative for analysis of FA composition. Before analysis, these samples were thawed and pooled by period in proportion to daily milk yield. Milk FA profiles were determined according to the procedure described by Boivin et al. (2013).

Rumen Fluid. Fluid was collected on d 11 and 12 (one square per day) of each period from the ventral sac of the rumen using a 50-mL syringe screwed to a stainless tube ending with a probe covered by a fine metal mesh (RT rumen fluid collection tube; Bar Diamond Inc., Parma, ID), as described by Benchaar et al. (2013). Samples were collected at $0,1,2,4,6,8,10$, and $12 \mathrm{~h}$ relative to feeding time. The $\mathrm{pH}$ of harvested rumen fluid was immediately measured (pHTestr 30; Oakton Instruments, Vernon Hills, IL). A 10-mL sample was pipetted into a glass vial containing $0.2 \mathrm{~mL}$ of sulfuric acid $(50 \%)$, and stored at $-20^{\circ} \mathrm{C}$.

For the analysis of $\mathrm{NH}_{3}-\mathrm{N}$ and VFA, the samples of rumen fluid collected in the glass vials were thawed at room temperature, transferred to $15-\mathrm{mL}$ conical tubes, centrifuged at $25,200 \times g$ for 15 min at $4^{\circ} \mathrm{C}$, and transferred to microtubes. Concentration of $\mathrm{NH}_{3}-\mathrm{N}$ was determined as in Weatherburn (1967) using a Varioskan spectrophotometer (type 3001, Thermo Electron Corporation, Vantaa, Finland) at $625 \mathrm{~nm}$. The profile of ruminal VFA was determined with a gas chromatograph (Agilent 6890N; Agilent Technologies Canada Inc.) equipped with a DB FFAP capillary column (30 m $\times 0.25 \mathrm{~mm}$ i.d. $\times 0.25 \mu \mathrm{m}$ film; Agilent Technologies Canada Inc.), and a flame ionization detector. The split ratio was 25:1. At the time of the sample injection the column temperature was $80^{\circ} \mathrm{C}$, maintained for $0.5 \mathrm{~min}$, followed by a first increase to $180^{\circ} \mathrm{C}$ at $10^{\circ} \mathrm{C} / \mathrm{min}$, and a second increase to $220^{\circ} \mathrm{C}$ at $30^{\circ} \mathrm{C} / \mathrm{min}$. The temperature was then maintained at $220^{\circ} \mathrm{C}$ for $2 \mathrm{~min}$. All ruminal fluid samples were assayed in triplicate.

\section{Statistical Analysis}

Data were analyzed with the MIXED procedure of SAS (version 9.4; SAS Institute Inc., Cary, NC). Because no square effect was observed it was removed from the model and data were analyzed as a duplicated $4 \times 4$ Latin square design according to the following model:

$$
\mathrm{Y}_{\mathrm{ijk}}=\mu+\mathrm{T}_{\mathrm{i}}+\mathrm{P}_{\mathrm{j}}+(\mathrm{T} \times \mathrm{P})_{\mathrm{ij}}+\mathrm{C}_{\mathrm{k}}+\varepsilon_{\mathrm{ijk}},
$$

where $Y_{\mathrm{ijk}}=$ individual observation, $\mu=$ overall mean, $\mathrm{T}_{\mathrm{i}}=$ fixed effect of treatment $(\mathrm{i}=1$ to 4$), \mathrm{P}_{\mathrm{j}}=$ fixed effect of period $(\mathrm{j}=1$ to 4$),(\mathrm{T} \times \mathrm{P})_{\mathrm{ij}}=$ interaction between treatment and period, $\mathrm{C}_{\mathrm{k}}=$ random effect of cow $(\mathrm{k}=1$ to 8$), \varepsilon_{\mathrm{ijk}}=$ residual error term, and where the subject of the repeated statement was cow. Interaction between treatment and period was removed from the model when not significant. The covariance structure selection was based on the Akaike's information criterion. Satterthwaite's option was used to calculate the denominator degrees of freedom. To discriminate the different effects of lipid supplementation on mammary lipogenesis and the resulting effect on milk OBCFA concentrations and yields, preplanned contrasts were established as follows: PUFA supplementation in the rumen against the control (RSO vs. CTL), PUFA supplementation against SFA supplementation in the rumen (RSO vs. RSF), and SFA supplementation in the rumen against SFA supplementation in the abomasum (RSF vs. ASF). Correlations between individual milk FA and rumen VFA concentrations were analyzed using the REG procedure of SAS (SAS Institute Inc.).

For statistical evaluation of the relationship between milk FA profile and rumen $\mathrm{pH}$, a correlation analysis was first performed to calculate the Pearson coefficients of correlation (CORR procedure of SAS) of each individual milk FA concentration. Milk FA for which a significant relationship with rumen $\mathrm{pH}$ was observed were included in a selection procedure for multiple regression using a stepwise procedure (GLMSELECT of SAS) with rumen $\mathrm{pH}$ being the dependent variable and stepwise selection of milk FA based on the Schwarz Bayesian information criterion. The selected model was then evaluated using the REG procedure of SAS in terms of multicollinearity (variance inflation factor $>10$ ), high influence and leverage observations by DFFITS $[>2 \sqrt{ }(p / n)$, where $p$ is the number of parameters estimated in the model and $n$ the number of observations], Cook's distance $(>4 / n)$, and homoscedasticity by the normality of the residuals. The model was then fitted into a random regression using the MIXED procedure of SAS including cow as the subject of a random intercept, and of the repeated statement. The TYPE $=\mathrm{VC}$ (variance component) structure provided best fit for both the random and the repeated statements. Denominator degrees of freedom were calculated by the Satterthwaite equation. The associations between observed rumen $\mathrm{pH}$ and the values predicted by the model were evaluated by linear regression. In addition, prediction bias was assessed by regressing residuals against predicted values as described by Rico et al. (2016), and based on St-Pierre (2003). Results are reported as least 
squares means, considered significant when $P \leq 0.05$, and reported as a tendency when $P<0.10$.

\section{RESULTS AND DISCUSSION}

\section{Cow Performance}

Infusing RSO increased DMI as compared with CTL (Table 4). As summarized by Allen (2000), lipid supplementation has resulted in higher DMI in several studies; this author proposed that substitution of fat for grain can reduce the hypophagic effects of propionate by reducing its flux to the liver, a situation that does not apply to the current trial where soybean oil was infused into the rumen and where grain supplementation was not different between treatments. Allen (2000) also suggested that dietary FA have a lower heat increment than other energy sources. Inclusion of fat in diets would therefore allow for a greater DM consumption according to the concept of thermostatic control of feed intake (Bhattacharya and Warner, 1968).

Moreover, DMI tended to be lower in cows receiving ASF as compared with RSF (Table 4). Dietary fat is a potent stimulator of cholecystokinin release in the small intestine, and evidence exists that this hormone contributes to satiety (Allen, 2000). It could be hypothesized that abomasally infused fat (ASF) could have contributed to a greater stimulation of cholecystokinin secretion, potentially through a more intimate contact with duodenum epithelium, as compared with ruminally infused fat (RSF), a phenomenon that could not be assessed in the current experiment.
Cows receiving RSO gained more weight as compared with CTL (Table 4). Although the length of the experimental periods was relatively short, the positive effect on BW gain could be explained by a greater DMI $(+1.1 \mathrm{~kg} / \mathrm{d}$; Table 4$)$, including the energy provided by soybean oil infusion $(450 \mathrm{~g} / \mathrm{d})$. No differences were observed for actual milk yield in any of tested contrasts, but fat and protein yields were higher for RSO than for CTL, as were ECM (Table 4). The increase in ECM for RSO compared with CTL is explained by cows receiving RSO having numerically higher actual milk yield and fat percentage. Such a positive effect on the yield of ECM and milk constituents could be explained by a higher feed consumption combined with the additional energy provided by the ruminally infused soybean oil.

Fat percentage and yield, as well as protein yield, were higher for cows receiving RSF compared with cows receiving RSO. Likewise, ECM was also higher for RSF than for RSO. We noted no significant differences on fat and protein percentages and yields between RSF and ASF (Table 4).

Rabiee et al. (2012) reviewed the effects of feeding saturated versus unsaturated fat supplements on milk yield and composition. In accordance with the results of the current experiment, Jenkins and Jenny (1992) observed no effect on DMI, but reported an increase in actual milk or FCM yield, and greater milk fat content and yield in cows fed prilled hydrogenated animal FA as compared with canola oil. On the contrary, in a more recent trial using Energy Booster 100, Abdelqader et al. (2009) reported no effect on the yield of milk, ECM,

Table 4. Dry matter intake, BW change, milk yield, and milk composition of cows receiving different lipid supplements

\begin{tabular}{|c|c|c|c|c|c|c|c|c|}
\hline \multirow[b]{2}{*}{ Parameter } & \multicolumn{4}{|c|}{ Treatment $^{1}$} & \multirow[b]{2}{*}{ SEM } & \multicolumn{3}{|c|}{$P$-value } \\
\hline & CTL & $\mathrm{RSO}$ & $\mathrm{RSF}$ & $\mathrm{ASF}$ & & $\begin{array}{c}\text { CTL vs. } \\
\text { RSO }\end{array}$ & $\begin{array}{c}\text { RSO vs. } \\
\text { RSF }\end{array}$ & $\begin{array}{c}\text { RSF vs } \\
\text { ASF }\end{array}$ \\
\hline BW change, ${ }^{3} \mathrm{~kg}$ & -4.71 & 3.30 & 2.06 & 3.09 & 2.46 & 0.05 & 0.74 & 0.78 \\
\hline \multicolumn{9}{|l|}{ Milk yield, $\mathrm{kg} / \mathrm{d}$} \\
\hline Actual & 36.1 & 36.9 & 36.4 & 36.1 & 1.83 & 0.72 & 0.83 & 0.90 \\
\hline Content, \% & 4.11 & 4.22 & 4.43 & 4.35 & 0.17 & 0.17 & 0.01 & 0.31 \\
\hline Yield, g/d & 1,495 & 1,588 & 1,709 & 1,655 & 74 & 0.01 & $<0.01$ & 0.13 \\
\hline \multicolumn{9}{|l|}{ Milk protein } \\
\hline Content, \% & 3.23 & 3.19 & 3.21 & 3.19 & 0.07 & 0.16 & 0.42 & 0.31 \\
\hline Yield, g/d & 1,170 & 1,206 & 1,244 & 1,216 & 43 & $<0.01$ & 0.03 & 0.08 \\
\hline \multicolumn{9}{|l|}{ Lactose } \\
\hline Content, \% & 4.71 & 4.73 & 4.71 & 4.69 & 0.03 & 0.30 & 0.23 & 0.28 \\
\hline
\end{tabular}

${ }^{1} \mathrm{CTL}=$ control; RSO $=$ soybean oil (Soya Excel Inc., Beloeil, QC, Canada) as a source of PUFA infused into the rumen; RSF $=$ SFA (Energy Booster 100, Milk Specialties Global, Eden Prairie, MN) infused into the rumen; ASF = SFA infused into the abomasum.

${ }^{2}$ Including ruminally or abomasally infused fat supplements.

${ }^{3}$ Over a 14 -d period.

${ }^{4}\{[23.8 \times($ protein yield in $\mathrm{kg} / \mathrm{d})]+[38.9 \times($ fat yield in $\mathrm{kg} / \mathrm{d})]+[16.3 \times($ lactose yield in $\mathrm{kg} / \mathrm{d})]\} / 3.14$ (Madsen et al., 2008). 
and fat, but an increase in milk fat concentration as compared with cows fed corn oil.

A decrease in milk fat content is expected when vegetable oils rich in cis-9,cis-12 18:2 (e.g., soybean or sunflower) are fed to dairy cows (Glasser et al., 2008). Such inhibition of milk fat synthesis has been attributed to a shift in PUFA biohydrogenation pathways occurring when rumen environment is altered (Bauman and Griinari, 2001), leading to the production of trans10,cis-12 18:2. This CLA isomer has been identified as an inhibitor of milk fat synthesis in lactating dairy cows (Bauman and Griinari 2001). However, in the current trial, milk fat percentage was not statistically different between RSO and CTL, despite the soybean oil representing $1.5 \%$ of DMI. As no significant levels of trans-10,cis-12 18:2 were found in the milk from cows receiving RSO treatment, we hypothesized that the continuous nature of the emulsified soybean oil infusions, at the current inclusion level, prevented the shift in ruminal biohydrogenation (Lanier and Corl, 2015) and thereby avoided the milk fat depression.

Nonetheless, milk fat content was lower with RSO as compared with RSF. Accordingly, a consistent increase in milk fat content has been observed in previous trials when prilled saturated fat supplements were compared with different sources of PUFA, such as canola oil (Jenkins and Jenny, 1992), corn oil (Abdelqader et al., 2009), and calcium soaps of UFA (Harvatine and Allen, 2006a). An analysis of the saturated fat supplement used in this experiment (Table 2) showed that it contained nearly $40 \%$ of each 16:0 and 18:0. As stated by Loften et al. (2014), dietary sources of 16:0 usually increase milk fat production, and supplying a mixture of 16:0 and 18:0 could optimize their utilization for milk production and overall performance in dairy cattle.

\section{Rumen Parameters}

Rumen $\mathrm{pH}$ was significantly lower for the RSO treatment than for the CTL or RSF (tendency) treatments (Table 5). There was no difference in rumen $\mathrm{pH}$ between cows receiving RSF and ASF treatments. In beef heifers, Krysl et al. (1991) reported a decrease in ruminal $\mathrm{pH}$ following a ruminal infusion of soybean oil. In dairy cows, Bateman and Jenkins (1998) reported linear and quadratic effects on ruminal $\mathrm{pH}$ as they increased soybean oil from 0 to $8 \%$ of diet DM. Specifically relevant to the results of the current experiment was that rumen $\mathrm{pH}$ decreased from 6.73 to 6.67 when soybean oil was included at $2 \%$ of DM. Nonetheless, previous work has indicated changes in $\mathrm{pH}$ above 6.2 do not affect ruminal fermentation (Pitt et al., 1996).

Total VFA concentration, proportions of individual VFA, and the acetate-to-propionate ratio were not affected by treatments (Table 5). Huang et al. (2008) also found no significant effects on total VFA concentration, or on individual VFA proportions between a control diet and a diet supplemented with soybean oil at $5 \%$ DM. When looking at the effects of SFA, Jenkins and Jenny (1992) found that prilled fat had no effect on total VFA content, acetate and propionate proportions, and acetate-to-propionate ratio when supplemented at $5 \%$ DM. However, when prilled fat was incrementally replaced by canola oil, linear decreases in total VFA content, acetate proportion, and acetate-to-propionate ratio were observed (Jenkins and Jenny, 1992).

\section{Milk FA}

Infusing RSO decreased the proportion of short- and medium-chain FA and increased milk fat content of most long-chain 18-carbon FA in milk fat (Table 6). These

Table 5. Ruminal pH, total VFA concentration, and VFA molar proportions of rumen cannulated cows receiving different lipid supplements

\begin{tabular}{|c|c|c|c|c|c|c|c|c|}
\hline \multirow[b]{2}{*}{ Variable } & \multicolumn{4}{|c|}{ Treatment $^{1}$} & \multirow[b]{2}{*}{ SEM } & \multicolumn{3}{|c|}{$P$-value } \\
\hline & CTL & $\mathrm{RSO}$ & RSF & ASF & & $\begin{array}{c}\text { CTL vs. } \\
\text { RSO }\end{array}$ & $\begin{array}{c}\text { RSO vs. } \\
\text { RSF }\end{array}$ & $\begin{array}{c}\text { RSF vs. } \\
\text { ASF }\end{array}$ \\
\hline Total VFA, mmol/L & 79.4 & 91.7 & 90.5 & 80.2 & 4.87 & 0.08 & 0.85 & 0.14 \\
\hline \multicolumn{9}{|c|}{ Individual VFA, mol/100 mol } \\
\hline Acetate & 63.38 & 65.07 & 65.68 & 65.53 & 1.77 & 0.50 & 0.81 & 0.95 \\
\hline Butyrate & 11.85 & 11.00 & 10.92 & 11.26 & 0.63 & 0.32 & 0.93 & 0.69 \\
\hline Isovalerate & 1.81 & 1.80 & 1.69 & 1.81 & 0.15 & 0.97 & 0.61 & 0.56 \\
\hline Valerate & 1.39 & 1.36 & 1.32 & 1.40 & 0.09 & 0.81 & 0.82 & 0.61 \\
\hline Caproate & 0.66 & 0.74 & 0.68 & 0.87 & 0.10 & 0.55 & 0.64 & 0.16 \\
\hline Acetate:propionate & 3.35 & 3.56 & 3.63 & 3.73 & 0.24 & 0.52 & 0.84 & 0.74 \\
\hline
\end{tabular}

${ }^{1} \mathrm{CTL}=$ control; RSO = soybean oil (Soya Excel Inc., Beloeil, QC, Canada) as a source of PUFA infused into the rumen; RSF $=$ SFA (Energy Booster 100, Milk Specialties Global, Eden Prairie, MN) infused into the rumen; ASF = SFA infused into the abomasum. 
effects are consistent with the reduction in de novo FA synthesis due to feeding unsaturated oils, which occurs as a result of greater uptake and secretion of dietaryderived FA (Palmquist et al., 1993). More specifically, infusion of RSO increased the proportions of 18:0, most of the cis and trans isomers of 18:1, as well as major biohydrogenation intermediates, such as trans-11, cis-15 18:2 and cis-9,trans-11 18:2, as compared with CTL and RSF (Table 6). These FA have been identified as the final product (18:0) or intermediates of ruminal biohydrogenation of cis-9,cis-12 18:2 and cis-9,cis-12,cis-15 18:3 (Shingfield and Wallace, 2014), the 2 major PUFA found in soybean oil (Table 2). In addition, infusion of RSF increased milk fat concentration of 16:0 as compared with RSO, which is consistent with the supply of this FA from Energy Booster 100 infusion.

We observed numerous treatment effects on individual milk OBCFA. Compared with CTL, RSO decreased the concentrations (Table 7) and yields (Table 8) of milk iso 13:0 and iso 15:0; anteiso 17:0 and the sum of anteiso FA; as well as 11:0, 13:0, 15:0, 17:0, and the sum of odd-chain FA (OCFA). Moreover, the concentration of iso 17:0 and the yield of iso 14:0 were increased by RSO, whereas no differences were observed for the concentrations and yields of iso 16:0 and iso 18:0 in milk between CTL and RSO (Tables 7 and 8).

Rumen amylolytic bacteria are enriched in anteiso FA and OCFA, whereas cellulolytic bacteria have higher levels of iso FA, as stated by Fievez et al. (2012). Maia et al. (2007) reported that rumen bacteria, particularly cellulolytic bacteria, are negatively affected by PUFA. However, as the concentrations and yields of odd iso and even iso FA in milk were not affected by RSO, it seems unlikely that RSO, at the current level of supplementation, had toxic effects on rumen bacteria. This is further evidence that the continuous infusion of the emulsified soybean oil helped diminish the negative effects normally associated with feeding PUFA. Whereas the reason for the decrease in proportions of anteiso FA and OCFA with RSO is not immediately clear, one could hypothesize that the increase in DMI with RSO could be effecting rumen bacteria and, thus, the milk OBCFA concentrations and yields. Alternatively, it has been established that rumen bacteria take up dietary FA and that lipid supplementation increases this uptake and decreases OBCFA synthesis by rumen bacteria (Bauchart et al., 1990; Weisbjerg et al., 1992). These findings corroborate with the current results in milk FA profile, where the proportion of OBCFA in relationship to total FA decreased for RSO. One possibility to explain why RSO decreased milk proportions of anteiso FA and OCFA compared with CTL, but did not affect even iso FA, may be that amylolytic bacteria are more adept replacing de novo FA synthesis with uptake of dietary FA than cellulolytic bacteria. Although this idea requires further research, it could be supported by the observation that amylolytic bacteria are less sensitive to exogenous FA than cellulolytic strains (Doreau and Ferlay, 1995).

The RSF treatment significantly increased the concentrations and yields of milk anteiso 13:0, anteiso 17:0, and the sum of anteiso FA; 17:0, cis-9 17:1, and the sum of OCFA; iso 18:0; and total OBCFA, compared with RSO (Tables 7 and 8). The proportions of anteiso 13:0 and iso 18:0 were very low, so drawing any conclusions about the biological meanings of their variations in milk fat is difficult. The increase in concentration of 17:0 and cis-9 17:1 with RSF as compared with RSO is due to the SFA supplement used in the current experiment which contained $2 \%$ of 17:0 + cis-9 17:1 (Table 2). It is important to consider cis-9 17:1 together with 17:0 when looking at OBCFA in milk, as it has been shown that the $\Delta^{9}$-desaturase activity in the mammary gland converts biologically important quantities of $17: 0$ to cis-9 17:1 (Fievez et al., 2003). Infusing RSF at the rate of $450 \mathrm{~g} / \mathrm{d}$ therefore provided a total supply of 9 $\mathrm{g} / \mathrm{d}$ of 17:0 + cis-9 17:1, which were transferred in milk fat with an apparent efficiency of $46 \%$ for RSF and $42 \%$ for ASF, as calculated as recovery above the CTL treatment.

The increased proportion of anteiso 17:0 in the milk of cows receiving $\mathrm{RSF}$ compared with $\mathrm{RSO}$, and the fact that this proportion numerically resembled the proportion from cows on CTL and ASF, gives rise to speculation that the PUFA in the soybean oil influenced this result. Whereas protozoa were found to contain lower levels of most OBCFA compared with rumen bacteria, they did have higher levels of anteiso 17:0 and UFA (Or-Rashid et al., 2007), which have been implicated with maintaining microbial membrane fluidity (Hauser et al., 1979). Based on this information, hypotheses to explain the depressed level of milk anteiso 17:0 for RSO would be that (1) soybean oil PUFA inhibited the growth of rumen protozoa, as reported by Doreau and Ferlay (1995), or (2) rumen protozoa were able to use some of the UFA from the soybean oil in place of de novo-synthesized anteiso 17:0 to maintain membrane fluidity.

We noted limited differences in the milk OBCFA profile between RSF and ASF. Among few exceptions, concentrations and yields of iso 14:0, iso 15:0, and iso 16:0 increased in milk from cows receiving ASF as compared with RSF (Tables 7 and 8). These FA are higher in cellulolytic bacteria, so the results indicate that infusing the emulsified SFA supplement directly into the rumen may have affected fiber digestion, or the growth of cellulolytic bacteria and their de novo FA synthesis. Similarly, Harvatine and Allen (2006b) 
Table 6. Milk fat composition for cows receiving different lipid supplements ${ }^{1}$

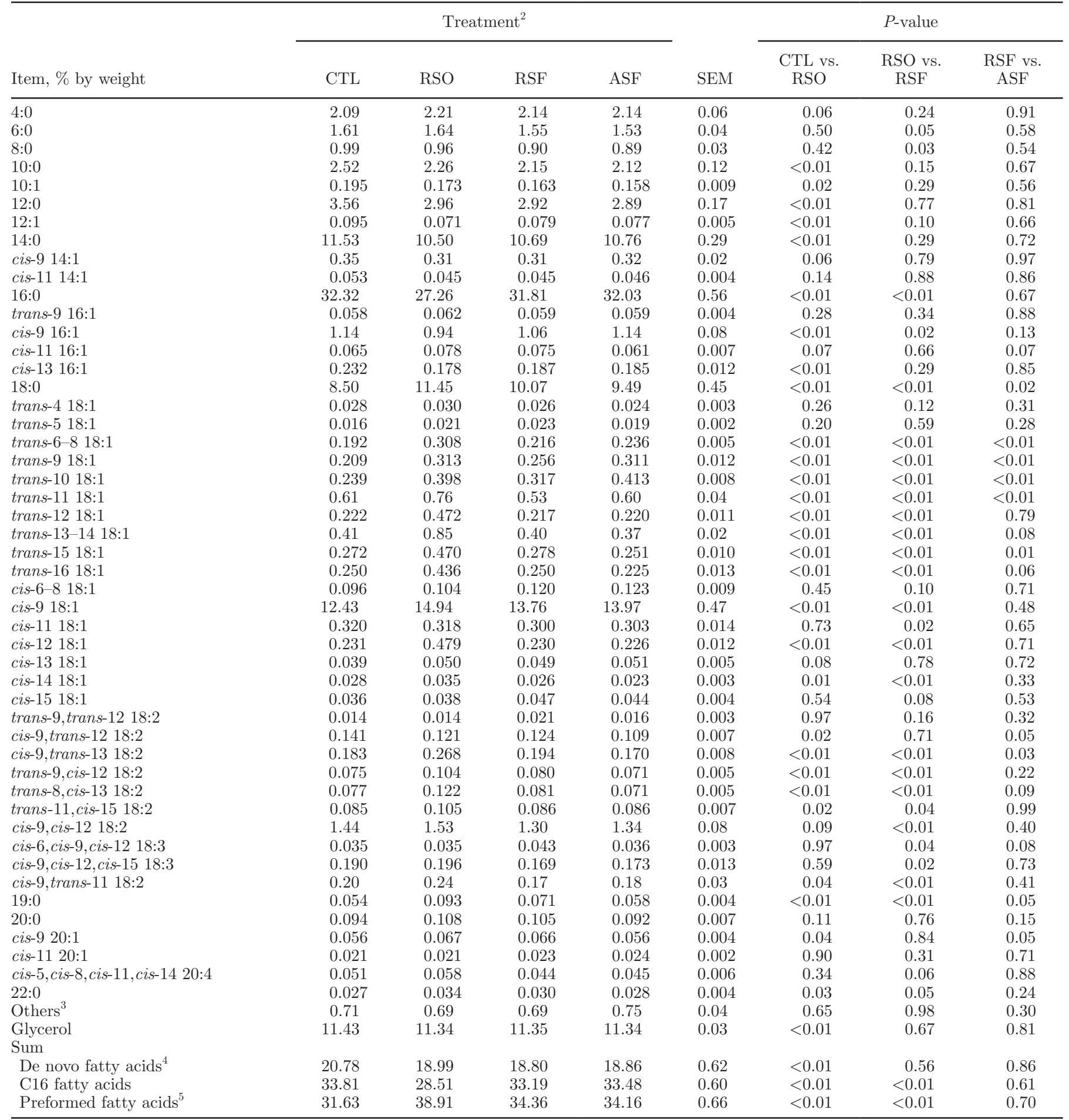

${ }^{1}$ Excluding odd- and branched-chain fatty acids.

${ }^{2} \mathrm{CTL}=$ control; RSO = soybean oil (Soya Excel Inc., Beloeil, QC, Canada) as a source of PUFA infused into the rumen; RSF = SFA (Energy Booster 100, Milk Specialties Global, Eden Prairie, MN) infused into the rumen; ASF = SFA infused into the abomasum.

${ }^{3}$ Represent unidentified chromatogram peaks.

${ }^{4}$ Sum of straight even-chain fatty acids from C6 to C14.

${ }^{5}$ Sum of odd- and branched-chain fatty acids (Table 7), and all fatty acids with a carbon chain length of 17 or more. 
Table 7. Milk fat content of odd- and branched-chain fatty acids for cows receiving different lipid supplements

\begin{tabular}{|c|c|c|c|c|c|c|c|c|}
\hline \multirow[b]{2}{*}{ Item, $\%$ by weight } & \multicolumn{4}{|c|}{ Treatment $^{1}$} & \multirow[b]{2}{*}{ SEM } & \multicolumn{3}{|c|}{$P$-value } \\
\hline & CTL & $\mathrm{RSO}$ & RSF & ASF & & $\begin{array}{c}\text { CTL vs. } \\
\text { RSO }\end{array}$ & $\begin{array}{c}\text { RSO vs. } \\
\text { RSF }\end{array}$ & $\begin{array}{c}\text { RSF vs. } \\
\text { ASF }\end{array}$ \\
\hline \multicolumn{9}{|l|}{ Odd iso fatty acids } \\
\hline iso $15: 0$ & 0.190 & 0.166 & 0.168 & 0.179 & 0.006 & $<0.01$ & 0.58 & 0.02 \\
\hline iso 17:0 & 0.112 & 0.127 & 0.124 & 0.130 & 0.005 & 0.04 & 0.64 & 0.34 \\
\hline iso 14:0 & 0.136 & 0.147 & 0.140 & 0.174 & 0.011 & 0.20 & 0.40 & $<0.01$ \\
\hline iso $16: 0$ & 0.351 & 0.344 & 0.345 & 0.426 & 0.031 & 0.82 & 0.96 & 0.02 \\
\hline iso 18:0 & 0.017 & 0.017 & 0.024 & 0.016 & 0.002 & 0.74 & $<0.01$ & $<0.01$ \\
\hline Sum of even iso fatty acids & 0.504 & 0.507 & 0.508 & 0.616 & 0.039 & 0.93 & 0.97 & 0.01 \\
\hline \multicolumn{9}{|l|}{ Anteiso fatty acids } \\
\hline anteiso 13:0 & 0.022 & 0.016 & 0.022 & 0.015 & 0.002 & 0.05 & 0.02 & 0.01 \\
\hline anteiso 15:0 & 0.817 & 0.750 & 0.748 & 0.792 & 0.056 & 0.05 & 0.95 & 0.19 \\
\hline $15: 0$ & 1.221 & 1.024 & 1.074 & 1.060 & 0.041 & $<0.01$ & 0.18 & 0.69 \\
\hline $17: 0$ & 0.480 & 0.428 & 0.621 & 0.618 & 0.012 & $<0.01$ & & 0.81 \\
\hline cis-7 17:1 & 0.036 & 0.041 & 0.059 & 0.060 & 0.004 & 0.23 & $<0.01$ & 0.86 \\
\hline cis-8 $17: 1$ & 0.017 & 0.019 & 0.018 & 0.018 & 0.002 & 0.10 & 0.56 & 0.64 \\
\hline cis-9 17:1 & 0.146 & 0.132 & 0.171 & 0.174 & 0.007 & 0.01 & $<0.01$ & 0.46 \\
\hline Sum of odd-chain fatty acids & 2.106 & 1.809 & 2.107 & 2.086 & 0.057 & $<0.01$ & $<0.01$ & 0.72 \\
\hline Sum of odd- and branched-chain fatty acids & 4.116 & 3.683 & 4.057 & 4.194 & 0.104 & $<0.01$ & $<0.01$ & 0.05 \\
\hline
\end{tabular}

${ }^{1} \mathrm{CTL}=$ control; RSO = soybean oil (Soya Excel Inc., Beloeil, QC, Canada) as a source of PUFA infused into the rumen; RSF $=$ SFA (Energy Booster 100, Milk Specialties Global, Eden Prairie, MN) infused into the rumen; ASF = SFA infused into the abomasum.

Table 8. Yield of milk odd- and branched-chain fatty acids for cows receiving different lipid supplements

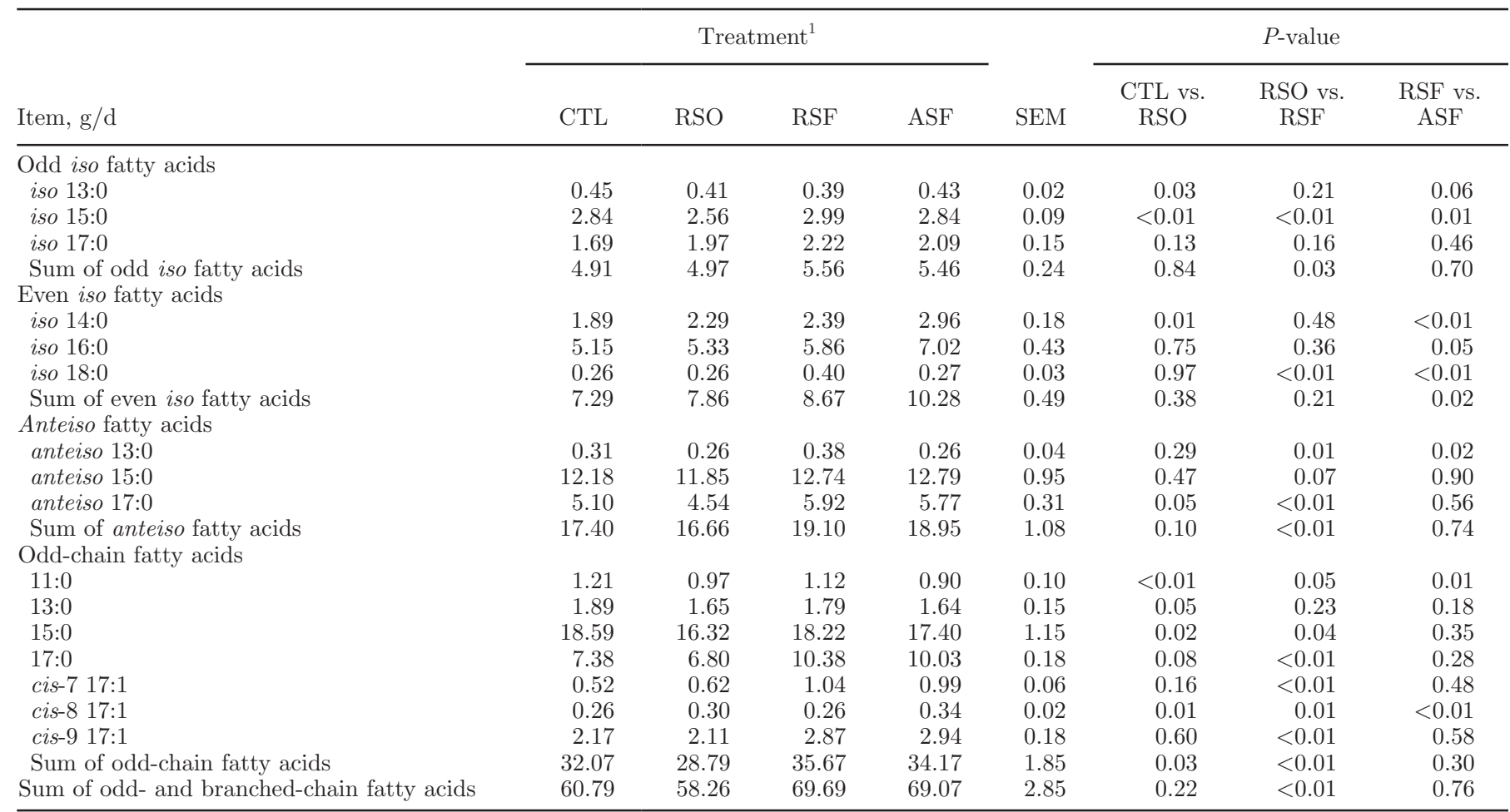

${ }^{1} \mathrm{CTL}=$ control; RSO = soybean oil (Soya Excel Inc., Beloeil, QC, Canada) as a source of PUFA infused into the rumen; RSF $=$ SFA (Energy Booster 100, Milk Specialties Global, Eden Prairie, MN) infused into the rumen; ASF = SFA infused into the abomasum. 
reported reduced NDF digestibility even when a highly saturated fat supplement, such as Energy Booster 100, was fed, and speculated this could be due to increased rumination, which in turn may have increased passage rate of digestible NDF from the rumen. However, it is not possible to confirm their hypothesis based on the current results, as rumination activity was not measured for our experiment. Furthermore, Harvatine and Allen (2006b) noted that fat supplementation decreased total rumen VFA, the proportion of acetate and the acetate-to-propionate ratio; these effects were not observed in the current experiment.

Interestingly, variations of milk branched-chain FA have been observed despite the fact that relative proportions of their precursors in the rumen (i.e., isobutyrate and isovalerate) were not different between treatments (Table 5). This observation suggests that VFA substrates are not limiting in the rumen, and that synthesis of branched-chain FA is more associated with the metabolic preference of some species of bacteria for those FA (Bas et al., 2003).

\section{Milk FA and Rumen Parameters}

Fievez et al. (2012) suggested the use of a combination of specific milk FA and a monitoring of variations in milk FA profile over an extended period of time to evaluate rumen acidosis. In the current experiment, a multiple regression analysis allowed the estimation of rumen $\mathrm{pH}$ using milk FA concentrations, after correction for the random effect of cow $\left(P<0.001, \mathrm{R}^{2}=0.81\right.$; Figure 1):

$$
\begin{aligned}
\mathrm{pH} & =6.24-(0.56 \times 4: 0)+(1.67 \times \text { iso } 14: 0) \\
& +(4.22 \times \text { iso } 15: 0)+(9.41 \times 22: 0)
\end{aligned}
$$

The positive relationship between iso FA and rumen $\mathrm{pH}$ is to be expected, given that these FA are, as previously discussed, related to cellulolytic bacteria, which are negatively affected by low rumen $\mathrm{pH}$ (Russell and Wilson, 1996). Limited information was found on 22:0 in relation to rumen $\mathrm{pH}$. Among the data available, mixed rumen bacteria harvested from dairy cows have been shown to contain more than $1 \%$ of this longchain SFA (Or-Rashid et al., 2007). Moreover, Bas et al. (2003) reported that the concentration of 22:0 decreased significantly in microbial cell mass of duodenal digesta when the level of concentrate increased in the diet of dairy goats. Ruminal $\mathrm{pH}$ was not reported by Bas et al. (2003), but their data suggest that relative proportion of 22:0 could be affected by ruminal fermentation and consequently on microbial synthesis of this FA. Consistent with these observations, Boivin et al. (2013) observed a concomitant decrease in rumen $\mathrm{pH}$ and milk fat concentration of 22:0 when dairy cows received a diet higher in starch (whole corn silage vs. earless corn silage).

Very few data were found regarding milk 4:0 and rumen $\mathrm{pH}$. Butyrate is produced during fermentation in the rumen, and its relative proportions in VFA profile have been shown to increase with a decrease in ruminal pH (Esdale and Satter, 1972). DeFrain et al. (2004) reported that during absorption, butyrate is converted to BHB, mainly in the rumen wall before its release into circulation. The same authors have shown that dietary treatments increasing the proportion of butyrate among VFA in the rumen also raises the concentration of BHB in blood plasma. In the mammary gland,

\section{(a)}

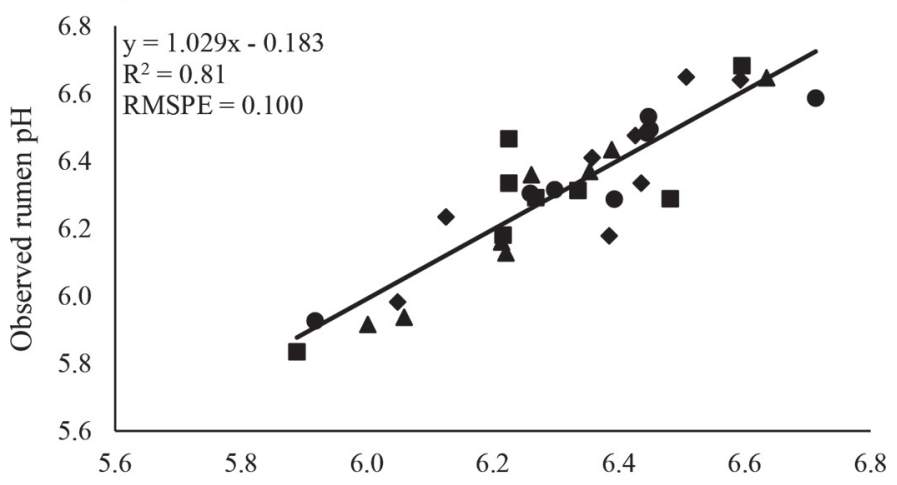

(b)

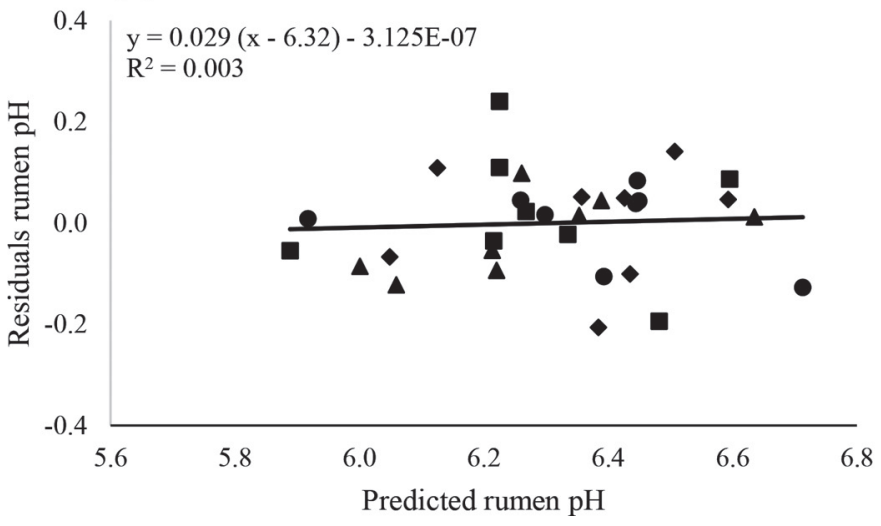

Figure 1. Associations between observed and predicted rumen $\mathrm{pH}$ accounting for cow and period variation obtained from cows receiving different lipid supplements: $\bullet=$ control; $\boldsymbol{\Delta}=$ soybean oil (Soya Excel Inc., Beloeil, QC, Canada) as a source of PUFA infused into the rumen; - = SFA (Energy Booster 100, Milk Specialties Global, Eden Prairie, MN) infused into the rumen; $\boldsymbol{}=\mathrm{SFA}$ infused into the abomasum. (a) The association between model predicted and observed values. (b) The association between model predicted values and residuals. The equation in (b) was obtained from the association between predicted rumen $\mathrm{pH}$ centered around the mean of predicted values and residuals. The mean $(-3.125 \mathrm{E}-07)$ and linear $(0.029)$ biases were not different from $0(P>0.75)$. RMSPE $=$ root mean square prediction error. 
(a)
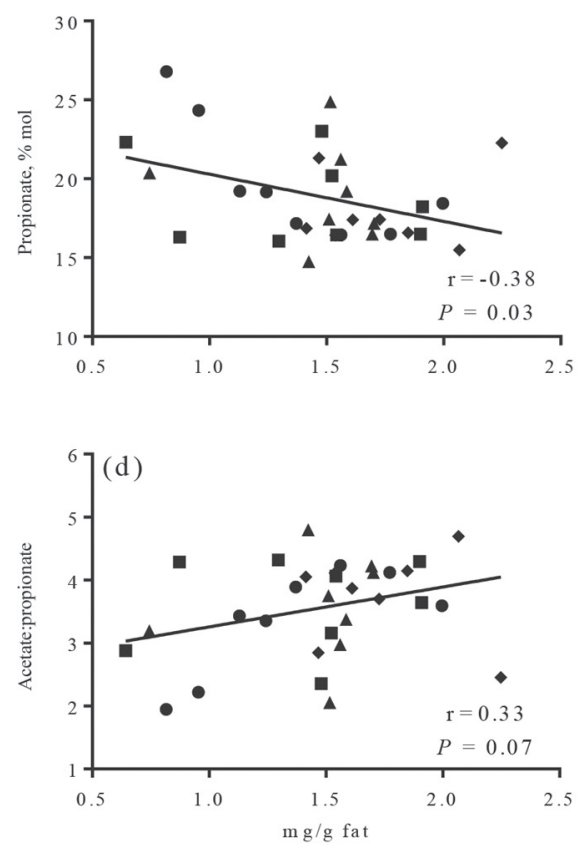

(b)
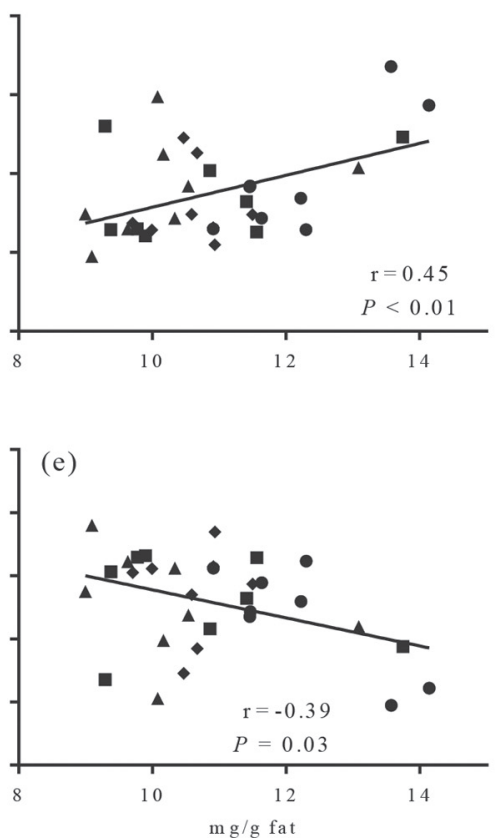

(c) $17: 0+c i s-917: 1$
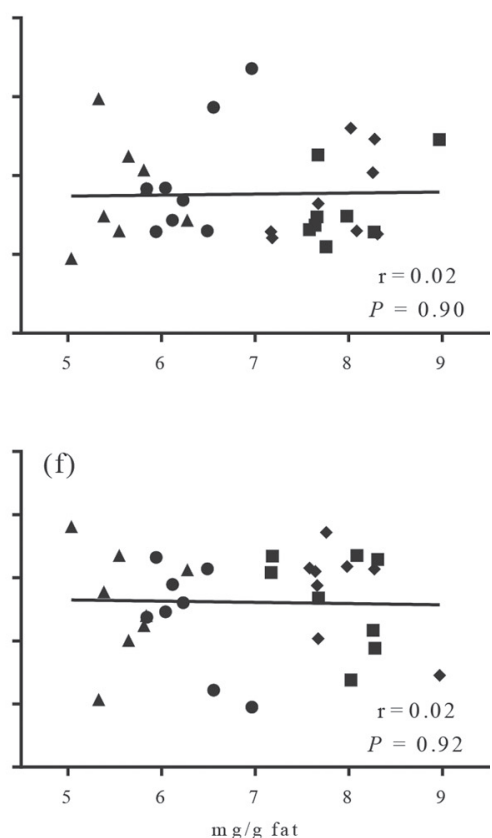

Figure 2. Associations between rumen propionate concentration and milk fat concentration of (a) iso 14:0; (b) 15:0; (c) 17:0 + cis-9 17:1, and between rumen acetate-to-propionate ratio and milk fat concentration of (d) iso 14:0; (e) 15:0; (f) 17:0 + cis-9 17:1 obtained from cows receiving different lipid supplements: $\bullet=$ control; $\boldsymbol{\Delta}=$ soybean oil (Soya Excel Inc., Beloeil, QC, Canada) as a source of PUFA infused into the rumen; = SFA (Energy Booster 100, Milk Specialties Global, Eden Prairie, MN) infused into the rumen; $\bullet=$ SFA infused into the abomasum.

about half of 4:0 arises directly from BHB (Palmquist et al., 1993). In the current experiment, no differences were observed for ruminal butyrate concentration in any of tested contrasts (Table 5). However, this series of metabolic events could explain the observed inverse relationship between rumen $\mathrm{pH}$ and milk fat content of 4:0 on an individual cow basis.

An analysis of the relationship between individual rumen VFA and milk OBCFA was also performed, regardless of lipid treatments. The molar percentage of propionate was inversely related to milk iso 14:0 (Figure 2a), whereas it was positively correlated with milk 15:0 (Figure 2b). The acetate-to-propionate ratio tended to be positively correlated with iso 14:0 (Figure 2d) and was negatively correlated with 15:0 (Figure 2e). These relationships are as expected given the association between iso 14:0 and cellulolytic bacteria, which produce acetate, and between 15:0 and amylolytic bacteria, which produce propionate (Fievez et al., 2012). However, we found no significant correlation between 17:0 + cis-9 17:1 and the molar percentage of propionate (Figure 2c) or the acetate-to-propionate ratio (Figure 2f). This lack of relationship is in contrast with Vlaeminck et al. (2006b), who examined data from 10 feeding experiments and found that 17:0 + cis-9 17:1 was negatively correlated with acetate and positively correlated with propionate. The lack of a significant relationship in the current experiment between the sum of these 2 milk FA and rumen VFA was likely due to the presence of 17:0 and cis-9 17:1 in SFA supplement, which underlines the effect that the FA profile of lipid supplements can have on the attempt to establish robust relationships between the milk OBCFA profile and rumen parameters.

\section{CONCLUSIONS}

This experiment evaluated the effect that lipid supplementation may have on cow performance, rumen parameters, the milk OBCFA profile, and the relationships between milk OBCFA and rumen parameters. Infusing RSO increased the production of milk fat as compared with CTL treatment. The continuous nature of the infusion and the emulsified form of soybean oil seemed to have alleviated the negative effects PUFA can have on rumen fermentation and milk fat synthesis in the mammary gland. When ruminally infused, saturated fat compared with PUFA increased the yield of ECM as well as milk fat and protein. Lipid supply had limited effects on rumen parameters in this experiment, though the RSO treatment did decrease mean rumen pH. Numerous effects of lipid supplementation 
were observed on the milk OBCFA profile, notably an increase in milk 17:0 + cis-9 17:1 when cows received the RSF and ASF treatments, presumably due to the presence of 17:0 in Energy Booster 100, indicating that the FA profile of lipid supplements given to lactating dairy cows can affect the milk OBCFA profile. The presence of this 17:0 in the supplement also affected the relationships between milk OBCFA and rumen VFA. Milk fat concentrations of 4:0, iso 14:0, iso 15:0, and 22:0 can be useful to predict rumen $\mathrm{pH}$, though the regression remains to be verified using an independent data set. Analyzing the milk OBCFA profile continues to be a promising, noninvasive method for evaluating rumen function, though the FA profile of dietary lipid supplements when used in the diet must be considered in the development of a diagnostic tool to evaluate rumen parameters based on the milk OBCFA profile.

\section{ACKNOWLEDGMENTS}

This experiment was funded through Industrial Research Chair program of the Natural Sciences and Engineering Research Council of Canada (Ottawa, ON, Canada), with industry contributions from Dairy Farmers of Canada (Ottawa, ON, Canada), Novalait Inc. (Québec, QC, Canada), Valacta (Ste-Anne-de-Bellevue, QC, Canada), Les Producteurs de Lait du Québec (Longueuil, QC, Canada), and Ministère de l'Agriculture, des Pêcheries et de l'Alimentation du Québec (Québec, QC, Canada). The authors thank Micheline Gingras (Université Laval, Québec, QC, Canada) for her technical support, as well as Yan Martel-Kennes and Annie Dumas for their help in organizing the experiment at the farm, and André Perreault, Denis Lefebvre, and Sébastien Coursol for all their work in the barn at the Centre de Recherche en Sciences Animales de Deschambault (Deschambault, QC, Canada). Appreciation is also expressed to Soya Excel Inc. (Beloeil, QC, Canada) for providing the soybean oil.

\section{REFERENCES}

Abdelqader, M. M., A. R. Hippen, K. F. Kalscheur, D. J. Schingoethe, and A. D. Garcia. 2009. Isolipidic additions of fat from corn germ, corn distillers grains, or corn oil in dairy cow diets. J. Dairy Sci. 92:5523-5533. http://dx.doi.org/10.3168/jds.2008-1867.

Allen, M. S. 2000. Effects of diet on short-term regulation of feed intake by lactating dairy cattle. J. Dairy Sci. 83:1598-1624. http:// dx.doi.org/10.3168/jds.S0022-0302(00)75030-2.

AOAC International. 2005. Official Methods of Analysis. 18th ed. AOAC International, Arlington, VA.

Bas, P., H. Archimède, A. Rouzeau, and D. Sauvant. 2003. Fatty acid composition of mixed-rumen bacteria: Effect of concentration and type of forage. J. Dairy Sci. 86:2940-2948. http://dx.doi. org/10.3168/jds.S0022-0302(03)73891-0.

Bateman, H. G., and T. C. Jenkins. 1998. Influence of soybean oil in high fiber diets fed to nonlactating cows on ruminal unsaturated fatty acids and nutrient digestibility. J. Dairy Sci. 81:2451-2458 http://dx.doi.org/10.3168/jds.S0022-0302(98)70136-5.

Bauchart, D., F. Legay-Carmier, M. Doreau, and B. Gaillard. 1990. Lipid metabolism of liquid-associated and solid-adherent bacteria in rumen contents of dairy cows offered lipid-supplemented diets. Br. J. Nutr. 63:563-578. http://dx.doi.org/10.1079/BJN19900143.

Bauman, D. E., and J. M. Griinari. 2001. Regulation and nutritional manipulation of milk fat: low-fat milk syndrome. Livest. Prod. Sci 70:15-29. http://dx.doi.org/10.1016/S0301-6226(01)00195-6.

Benchaar, C., F. Hassanat, R. Gervais, P. Y. Chouinard, C. Julien, H. V. Petit, and D. I. Massé. 2013. Effects of increasing amounts of corn dried distillers grains with solubles in dairy cow diets on methane production, ruminal fermentation, digestion, $\mathrm{N}$ balance, and milk production. J. Dairy Sci. 96:2413-2427. http://dx.doi. org/10.3168/jds.2012-6037.

Bhattacharya, A. N., and R. G. Warner. 1968. Influence of varying temperature on central cooling and warming and on regulation of voluntary feed intake in dairy cattle. J. Dairy Sci. 51:1481-1489. http://dx.doi.org/10.3168/jds.S0022-0302(68)87216-9.

Boivin, M., R. Gervais, and P. Y. Chouinard. 2013. Effect of grain and forage fractions of corn silage on milk production and composition in dairy cows. Animal 7:245-254. http://dx.doi.org/10.1017/ S1751731112001486.

Canadian Council on Animal Care. 1993. Guidelines to the Care and Use of Experimental Animals. vol. 1, 2nd ed. CCAC, Ottawa, ON, Canada.

Dallaire, M. P., H. Taga, L. Ma, B. A. Corl, R. Gervais, Y. Lebeuf, F J. Richard, and P. Y. Chouinard. 2014. Effects of abomasal infusion of conjugated linoleic acids, Sterculia foetida oil, and fish oil on production performance and the extent of fatty acid $\Delta 9$-desaturation in dairy cows. J. Dairy Sci. 97:6411-6425. http://dx.doi. org/10.3168/jds.2013-7853.

DeFrain, J. M., A. R. Hippen, K. F. Kalscheur, and D. J. Schingoethe 2004. Feeding lactose increases ruminal butyrate and plasma $\beta$-hydroxybutyrate in lactating dairy cows. J. Dairy Sci. 87:24862494. http://dx.doi.org/10.3168/jds.S0022-0302(04)73373-1.

Doreau, M., and A. Ferlay. 1995. Effect of dietary lipids on nitrogen metabolism in the rumen: a review. Livest. Prod. Sci. 43:97-110. http://dx.doi.org/http://dx.doi.org/10.1016/0301-6226(95)00041I.

Drackley, J. K., T. H. Klusmeyer, A. M. Trusk, and J. H. Clark 1992. Infusion of long-chain fatty acids varying in saturation and chain length into the abomasum of lactating dairy cows. J. Dairy Sci. 75:1517-1526. http://dx.doi.org/10.3168/jds.S00220302(92)77908-9.

Emmanuel, B. 1978. The relative contribution of propionate, and longchain even-numbered fatty acids to the production of long-chain odd-numbered fatty acids in rumen bacteria. Biochim. Biophys. Acta 528:239-246. http://dx.doi.org/10.1016/0005-2760(78)90198-

Esdale, W. J., and L. D. Satter. 1972. Manipulation of ruminal fermentation IV. Effect of altering ruminal $\mathrm{pH}$ on volatile fatty acid production. J. Dairy Sci. 55:964-970. http://dx.doi.org/10.3168/ jds.S0022-0302(72)85603-0.

Ferguson, J. D., D. Sklan, W. V. Chalupa, and D. S. Kronfeld. 1990. Effects of hard fats on in vitro and in vivo rumen fermentation, milk production, and reproduction in dairy cows. J. Dairy Sci. 73:28642879. http://dx.doi.org/10.3168/jds.S0022-0302(90)78974-6.

Fievez, V., E. Colman, J. M. Castro-Montoya, I. Stefanov, and B. Vlaeminck. 2012. Milk odd- and branched-chain fatty acids as biomarkers of rumen function-An update. Anim. Feed Sci. Technol. 172:51-65. http://dx.doi.org/10.1016/j.anifeedsci.2011.12.008.

Fievez, V.. B. Vlaeminck, M. S. Dhanoa, and R. J. Dewhurst 2003. Use of principal component analysis to investigate the origin of heptadecenoic and conjugated linoleic acids in milk. J. Dairy Sci. 86:4047-4053. http://dx.doi.org/10.3168/jds.S00220302(03)74016-8.

Glasser, F., A. Ferlay, and Y. Chilliard. 2008. Oilseed lipid supplements and fatty acid composition of cow milk: A meta-analysis. J. Dairy Sci. 91:4687-4703. http://dx.doi.org/10.3168/jds.2008-0987. 
Gressley, T. F., S. M. Reynal, J. J. Olmos Colmenero, G. A. Broderick, and L. E. Armentano. 2006. Development of a tool to insert abomasal infusion lines into dairy cows. J. Dairy Sci. 89:3965-3967. http://dx.doi.org/10.3168/jds.S0022-0302(06)72438-9.

Harfoot, C. G. 1981. Lipid metabolism in the rumen. Pages 21-55 in Lipid Metabolism in Ruminant Animals. W. W. Christie, ed. Pergamon Press, New York, NY.

Harvatine, K. J., and M. S. Allen. 2006a. Effects of fatty acid supplements on milk yield and energy balance of lactating dairy cows. J. Dairy Sci. 89:1081-1091. http://dx.doi.org/10.3168/jds.S00220302(06)72176-2.

Harvatine, K. J., and M. S. Allen. 2006b. Effects of fatty acid supplements on ruminal and total tract nutrient digestion in lactating dairy cows. J. Dairy Sci. 89:1092-1103. http://dx.doi.org/10.3168/ jds.S0022-0302(06)72177-4.

Hauser, H., G. P. Hazlewood, and R. M. C. Dawson. 1979. Membrane fluidity of a fatty acid auxotroph grown with palmitic acid. Nature 279:536-538. http://dx.doi.org/10.1038/279536a0.

Huang, Y., J. P. Schoonmaker, B. J. Bradford, and D. C. Beitz. 2008. Response of milk fatty acid composition to dietary supplementation of soy oil, conjugated linoleic acid, or both. J. Dairy Sci. 91:260-270. http://dx.doi.org/10.3168/jds.2007-0344.

Jenkins, T. C. 2010. Technical note: Common analytical errors yielding inaccurate results during analysis of fatty acids in feed and digesta samples. J. Dairy Sci. 93:1170-1174. http://dx.doi.org/10.3168/ jds.2009-2509.

Jenkins, T. C., and B. F. Jenny. 1992. Nutrient digestion and lactation performance of dairy cows fed combinations of prilled fat and canola oil. J. Dairy Sci. 75:796-803. http://dx.doi.org/10.3168/ jds.S0022-0302(92)77818-7.

Keeney, M., I. Katz, and J. Allison. 1962. On the probable origin of milk fat acids in rumen microbial lipids. J. Am. Oil Chem. Soc. 39:198-201. http://dx.doi.org/10.1007/BF02635818.

Krysl, L. J., M. B. Judkins, and V. R. Bohman. 1991. Influence of ruminal or duodenal soybean oil infusion on intake, ruminal fermentation, site and extent of digestion, and microbial protein synthesis in beef heifers consuming grass hay. J. Anim. Sci. 69:2585-2590.

Lanier, J. S., and B. A. Corl. 2015. Challenges in enriching milk fat with polyunsaturated fatty acids. J. Anim. Sci. Biotechnol. 6:26. http://dx.doi.org/10.1186/s40104-015-0025-0.

Loften, J. R., J. G. Linn, J. K. Drackley, T. C. Jenkins, C. G. Soderholm, and A. F. Kertz. 2014. Invited review: Palmitic and stearic acid metabolism in lactating dairy cows. J. Dairy Sci. 97:46614674. http://dx.doi.org/10.3168/jds.2014-7919.

Madsen, T. G., M. O. Nielsen, J. B. Andersen, and K. L. Ingvartsen. 2008. Continuous lactation in dairy cows: Effect on milk production and mammary nutrient supply and extraction. J. Dairy Sci. 91:1791-1801. http://dx.doi.org/10.3168/jds.2007-0905.

Maia, M. R. G., L. C. Chaudhary, L. Figueres, and R. J. Wallace. 2007. Metabolism of polyunsaturated fatty acids and their toxicity to the microflora of the rumen. Antonie van Leeuwenhoek 91:303314. http://dx.doi.org/10.1007/s10482-006-9118-2.

Massart-Leën, A.-M., G. Peeters, G. Vandeputte-Van Messon, E. Roets, and C. Burvenich. 1986. Effects of valerate and isobutyrate on fatty acid secretion by the isolated perfused mammary gland of the lactating goat. Reprod. Nutr. Dev. 26:801-814. http://dx.doi. org/10.1051/rnd:19860505.

NRC. 2001. Nutrient Requirements of Dairy Cattle. 7th rev. ed. Natl. Acad. Press, Washington, DC.

Or-Rashid, M. M., N. E. Odongo, and B. W. McBride. 2007. Fatty acid composition of ruminal bacteria and protozoa, with emphasis on conjugated linoleic acid, vaccenic acid, and odd-chain and branched-chain fatty acids. J. Anim. Sci. 85:1228-1234. http:// dx.doi.org/10.2527/jas.2006-385.
Palmquist, D. L., A. D. Beaulieu, and D. M. Barbano. 1993. Feed and animal factors influencing milk fat composition. J. Dairy Sci. $\quad 76: 1753-1771 . \quad$ http://dx.doi.org/10.3168/jds.S00220302(93)77508-6.

Palmquist, D. L., and T. C. Jenkins. 1980. Fat in lactation rations. J. Dairy Sci. 63:1-14. http://dx.doi.org/10.3168/jds.S00220302(80)82881-5.

Pitt, R. E., J. S. Van Kessel, D. G. Fox, A. N. Pell, M. C. Barry, and P. J. Van Soest. 1996. Prediction of ruminal volatile fatty acids and $\mathrm{pH}$ within the net carbohydrate and protein system. J. Anim. Sci. 74:226-244.

Rabiee, A. R., K. Breinhild, W. Scott, H. M. Golder, E. Block, and I. J. Lean. 2012. Effect of fat additions to diets of dairy cattle on milk production and components: A meta-analysis and metaregression. J. Dairy Sci. 95:3225-3247. http://dx.doi.org/10.3168/ jds.2011-4895.

Rico, D. E., P. Y. Chouinard, F. Hassanat, C. Benchaar, and R. Gervais. 2016. Prediction of enteric methane emissions from Holstein dairy cows fed various forage sources. Animal 10:203-211. http:// dx.doi.org/10.1017/S1751731115001949.

Russell, J. B., and D. B. Wilson. 1996. Why are ruminal cellulolytic bacteria unable to digest cellulose at low pH? J. Dairy Sci. 79:15031509. http://dx.doi.org/10.3168/jds.S0022-0302(96)76510-4.

Shingfield, K. J., and R. J. Wallace. 2014. Synthesis of conjugated linoleic acid in ruminants and humans. Pages 1-65 in Conjugated Linoleic Acids and Conjugated Vegetable Oils. B. Sels and A. Philippaerts, ed. Royal Soc. Chem., London, UK. http://dx.doi. org/10.1039/9781782620211-00001.

St-Pierre, N. R. 2003. Reassessment of biases in predicted nitrogen flows to the duodenum by NRC 2001. J. Dairy Sci. 86:344-350. http://dx.doi.org/10.3168/jds.S0022-0302(03)73612-1.

Van Soest, P. J., F. B. Robertson, and B. A. Lewis. 1991. Methods for dietary fiber, neutral detergent fiber, and nonstarch polysaccharides in relation to animal nutrition. J. Dairy Sci. 74:3583-3597. http://dx.doi.org/10.3168/jds.S0022-0302(91)78551-2.

Villeneuve, M.-P., Y. Lebeuf, R. Gervais, G. F. Tremblay, J. C. Vuillemard, J. Fortin, and P. Y. Chouinard. 2013. Milk volatile organic compounds and fatty acid profile in cows fed timothy as hay, pasture or silage. J. Dairy Sci. 96:7181-7194. http://dx.doi. org/10.3168/jds.2013-6785.

Vlaeminck, B., V. Fievez, A. R. J. Cabrita, A. J. M. Fonseca, and R. J. Dewhurst. 2006a. Factors affecting odd- and branched-chain fatty acids in milk: A review. Anim. Feed Sci. Technol. 131:389-397. http://dx.doi.org/10.1016/j.anifeedsci.2006.06.017.

Vlaeminck, B., V. Fievez, S. Tamminga, R. J. Dewhurst, A. M. van Vuuren, D. De Brabander, and D. Demeyer. 2006b. Milk odd and branched-chain fatty acids in relation to the rumen fermentation pattern. J. Dairy Sci. 89:3954-3964. http://dx.doi.org/10.3168/ jds.S0022-0302(06)72437-7.

Vlaeminck, B., R. Gervais, M. M. Rahman, F. Gadeyne, M. Gorniak, M. Doreau, and V. Fievez. 2015. Postruminal synthesis modifies the odd- and branched-chain fatty acid profile from the duodenum to milk. J. Dairy Sci. 98:4829-4840. http://dx.doi.org/10.3168/ jds.2014-9207.

Weatherburn, M. W. 1967. Phenol-hypochlorite reaction for determination of ammonia. Anal. Chem. 39:971-974. http://dx.doi. org/10.1021/ac60252a045.

Weisbjerg, M. R., C. F. Børsting, and T. Hvelplund. 1992. The influence of tallow on rumen metabolism, microbial biomass synthesis and fatty acid composition of bacteria and protozoa. Acta Agric. Scand. Anim. Sci. 42:138-147. http://dx.doi. org/10.1080/09064709209410121. 